\title{
Seasonal dynamics of dissolved organic matter and microbial activity in the coastal North Sea
}

\author{
Eva Sintes ${ }^{1,2, *}$, Karen Stoderegger ${ }^{1}$, Veronica Parada ${ }^{1}$, Gerhard J. Herndl ${ }^{1,2}$ \\ ${ }^{1}$ Department of Biological Oceanography, Royal Netherlands Institute for Sea Research, PO Box 59, 1790 AB, \\ Den Burg, The Netherlands \\ ${ }^{2}$ Department of Marine Biology, Faculty Center of Ecology, University of Vienna, Althanstr. 14, 1090 Vienna, Austria
}

\begin{abstract}
The dynamics of dissolved organic matter (DOM) and microbial activity were monitored in the coastal North Sea over an annual cycle. DOM accumulated during the spring bloom towards the summer, associated with high phytoplankton extracellular release. Accumulation of dissolved organic carbon (DOC) occurred from April to June. During this period, based on the bacterial carbon demand (BCD) of the free-living bacteria and the photosynthetic extracellular release (PER), $85 \mu \mathrm{M}$ $\mathrm{C}$ were derived from sources other than direct DOC release by phytoplankton. Thereafter, from the end of August until December, the DOM concentrations decreased by about half. During this period, at least $269 \mu \mathrm{M} \mathrm{C}$ was removed from the system via the utilization by the bacterial community and/or sedimentation and export. Overall, our data indicate a pronounced seasonal shift in DOM sources supporting BCD. From spring to summer, BCD is almost fully supported by PER alone while in fall and winter, BCD is supported about equally by PER and by the DOM accumulated in the spring-summer period and originating presumably from a variety of DOM production mechanisms.
\end{abstract}

KEY WORDS: Bacterial activity $\cdot$ Dissolved organic matter $\cdot$ Production $\cdot$ Consumption $\cdot$ North Sea

\section{INTRODUCTION}

Bacteria play a key role in the geochemical cycles in aquatic ecosystems through the uptake of organic compounds and remineralization of inorganic nutrients. Since the development of the microbial loop concept by Azam et al. (1983), numerous studies have focused in determining the factors controlling bacteria in aquatic environments. Both bottom-up factors (i.e. resources), such as temperature and organic substrates (Pomeroy \& Wiebe 2001, Kirchman et al. 2009, van Wambeke et al. 2009), and top-down factors (e.g. predation by nanoflagellates and viruses) (Fuhrman 1999, Lee et al. 2001) have been shown to regulate planktonic bacterial populations. However, less is known about the control mechanisms on particle-attached bacteria.

Bacteria are known to actively colonize suspended particles (Grossart et al. 2006), supporting a relatively higher abundance and activity than the surrounding waters (Grossart et al. 2007). Nonetheless, flagellates and ciliates colonize particles and feed on attached prokaryotes (Artolozaga et al. 2002, Kiorbøe et al. 2004). Also, viruses exhibit elevated production on particle-attached bacteria as compared to the surrounding waters (Riemann \& Grossart 2008), although non-specific adsorption of viruses to particles is one of the major causes of viral inactivation and decay (Murray \& Jackson 1992). Viruses effectively attach to transparent exopolymer particles (TEP) (Mari et al. 2007). Up to $60 \%$ of the viruses suspended in the water column are adsorbed to particles (Hewson \& Fuhrman 2003) and thus will ultimately sediment out of the water column.

The coastal North Sea is a eutrophic environment, rich in inorganic nutrients and high biomass and production of phytoplankton (Cadée \& Hegeman 2002). One characteristic feature of the North Sea is the massive Phaeocystis spring bloom releasing copious amounts of dissolved organic mater (DOM) into the 
water (Cadée \& Hegeman 2002). Several studies have pointed out that exudation of mucopolysaccharides by Phaeocystis sp. is an important source of carbon for the microbial food web in the North Sea (Lancelot \& Mathot 1987). Additionally, when Phaeocystis blooms collapse, the release of intracellular organic carbon due to cell lysis and the mucilaginous matrix of the colonies leads to the formation of TEP (Mari et al. 2005), which together with other suspended particles of diverse origin can influence the abundance and distribution of planktonic microbes.

We hypothesized that the input of readily utilizable DOM and particulate organic matter (POM) of diverse origin leads to a bottom-up control of the free-living bacterial communities in the coastal North Sea while the dynamics of particle-attached bacteria are independent from variability in DOM and POM in the surrounding waters. Additionally, we hypothesized that the seasonal changes in DOM inputs and composition lead to shifts in the DOM sources supporting bacterial carbon demand in the coastal North Sea. To examine these hypotheses, the dynamics of dissolved organic substrates (carbon: DOC; nitrogen: DON; phosphorus: DOP; proteins) mediated by the microbial community were determined over an annual cycle. Variability in abundance and composition of the phytoplanktonic community, and flagellate and viral abundance was also monitored.

\section{MATERIALS AND METHODS}

Water samples were collected with an acid-rinsed bucket from the NIOZ jetty located at the southern entrance of the North Sea into the Dutch Wadden Sea $\left(53^{\circ} 00^{\prime} 18^{\prime \prime} \mathrm{N}, 04^{\circ} 47^{\prime} 42^{\prime \prime} \mathrm{E}\right)$ once or twice per week from 18 December 2002 to 12 December 2003. The NIOZ jetty is located at the Marsdiep tidal basin, and the subtidal water transport is mainly governed by tidal stress and wind (Buijsman \& Ridderinkhof 2007). The main freshwater input to this basin originates from Lake Ijssel (Zimmerman 1976), with an average discharge at the Den Oever sluice and the Kornwerderzand sluice of 333 and $239 \mathrm{~m}^{3} \mathrm{~s}^{-1}$, respectively, and a maximum discharge in fall and winter $>1000 \mathrm{~m}^{3}$ $\mathrm{s}^{-1}$ (Buijsman \& Ridderinkhof 2008). Sampling was carried out during high tide to collect incoming North Sea water.

Temperature and salinity were measured as part of the MARSDIEP monitoring series (Cadée \& Hegeman 2002) with a calibrated thermometer and a salinometer, respectively. Water samples used for biological and chemical analyses were pre-filtered through a $55 \mu \mathrm{m}$ Nitex screen to remove large particles including zooplankton.
The concentrations of dissolved inorganic nutrients $\left(\mathrm{NH}_{4}{ }^{+}, \mathrm{NO}_{3}{ }^{-}, \mathrm{NO}_{2}{ }^{-}, \mathrm{PO}_{4}{ }^{3-}\right)$ were determined after filtering the samples through $0.2 \mu \mathrm{m}$ filters (Acrodisc, Gelman Science) in a TRAACS 800 autoanalyzer system (see supplementary material available at www.intres.com/articles/suppl/a060p085_app.pdf)

Phytoplankton and primary production. Chlorophyll a (chl a) concentration was measured spectrophotometrically after filtering 0.5 to $1 \mathrm{l}$ of pre-screened water onto Whatman GF/F filters and extracting the pigments in acetone $(90 \% \mathrm{v} / \mathrm{v})$ in the dark at $4^{\circ} \mathrm{C}$ for $24 \mathrm{~h}$ (Lorenzen 1967). To calculate chl a concentrations, Lorenzen's (1967) formula was applied. Phytoplankton abundance and species composition were analyzed under a Zeiss inverted microscope on Lugol preserved samples (Philippart et al. 2007).

Particulate phytoplankton production (PPP) and photosynthetic extracellular release (PER) were measured as described by Teira et al. (2001). Briefly, four $30 \mathrm{ml}$ glass bottles ( 3 transparent bottles plus 1 dark bottle) were inoculated with 25 to $40 \mu \mathrm{Ci}$ (925 to $1480 \mathrm{kBq}$ ) of $\mathrm{NaH}^{14} \mathrm{CO}_{3}$ and incubated for $2 \mathrm{~h}$ under 2 different light regimens: under in situ conditions and under constant light intensity $\left(365.2 \mu \mathrm{E} \mathrm{m}^{-2} \mathrm{~s}^{-1}\right)$. Thereafter, the samples were gravity-filtered through Whatman GF/F filters. The filtrates were acidified with 40 to $75 \mu \mathrm{l}$ of $50 \% \mathrm{HCl}$ and bubbled with $\mathrm{N}_{2}$ while the filters were exposed to concentrated $\mathrm{HCl}$ fumes for $12 \mathrm{~h}$. The amount of radioactivity incorporated in organic matter was measured with a liquid scintillation counter (LKB Wallac, Model 1212) $18 \mathrm{~h}$ after adding the liquid scintillation cocktail. The disintegrations per minute (DPM) were converted to carbon fixation rates and the percentage of photosynthetic extracellular release (\% PER) calculated as: $\%$ PER $=$ PER $/($ PER + PPP $) \times 100$.

Depth-integrated primary production was calculated following Philippart et al. (2007); for more details see supplementary material available at www.int-res.com/ articles/suppl/a060p085_app.pdf.

Dissolved organic matter. Samples for DOC measurements were filtered through combusted Whatman GF/F filters using a combusted glass filtration system, and $8 \mathrm{ml}$ of the filtered samples were transferred to glass ampoules. The Whatman GF/F filters and all the glassware were combusted $\left(450^{\circ} \mathrm{C}\right.$ for $\left.4 \mathrm{~h}\right)$ prior to the filtration. After adding $50 \mu \mathrm{l}$ of $40 \%$ phosphoric acid to each sample, the ampoules were sealed and stored at $4^{\circ} \mathrm{C}$ in the dark until analysis. DOC concentrations were determined in triplicate using a Shimadzu TOC5000 analyzer (Benner \& Strom 1993).

Samples for dissolved DON and DOP were filtered through combusted Whatman GF/F filters, collected in acid-rinsed polyethylene flasks and stored frozen at $-20^{\circ} \mathrm{C}$ until analysis. Total dissolved nitrogen (TDN) 
and total dissolved phosphorus (TDP) were analyzed with a 13 TRAACS 800 continuous-flow analysis system following persulfate oxidation (Valderrama 1981). DON and DOP concentrations were obtained from the TDN and TDP concentrations by subtracting the sum of the inorganic nitrogen species and inorganic phosphate, respectively. The recovery efficiency of DON and DOP were 92 and $95 \%$, respectively (Kramer et al. 2005).

To determine the concentration of dissolved proteins, 2 to $5 \mathrm{l}$ of seawater were pre-filtered through $0.2 \mu \mathrm{m}$ polyethersulfone membranes (Vivaflow, VivaScience) and then concentrated by tangential flow ultrafiltration with low protein-binding polyethersulfone filters (Vivaflow, VivaScience) of $5 \mathrm{kDa}$ molecular weight cut off (MWCO) to a final volume of 20 to $50 \mathrm{ml}$. From these concentrates, $1 \mathrm{ml}$ was precipitated with trichloroacetic acid (TCA) to eliminate interfering substances and used for the colorimetric detection and quantification of total dissolved proteins by the bicinchoninic acid (BCA) assay (Smith et al. 1985). The protein pellet was re-suspended in the same working reagent as used for the reaction (Micro BCA protein assay kit, Pierce) and the absorbance of the mixture measured at $562 \mathrm{~nm}$ wavelength against Milli-Q water. The protein concentration from each sample was calculated from the blank-corrected absorbance versus the known concentrations of standard dilutions of bovine serum albumin (BSA, Pierce) assuming 100\% recovery. These standard curves were established daily. The percent recovery was not measured, but was probably lower than $100 \%$; for more details see supplementary material available at www.int-res.com/ articles/suppl/a060p085_app.pdf.

Bacterial abundance and activity. Bacterial abundance was determined by epifluorescence microscopy after DAPI-staining (Porter \& Feig 1980). Water samples $(10 \mathrm{ml})$ from unfiltered (hereafter termed 'whole community'), $3 \mu \mathrm{m}$ filtered ('free-living') and $0.8 \mu \mathrm{m}$ filtered seawater ('small free-living bacteria') were fixed with formaldehyde ( $2 \%$ final concentration), stained with DAPI ( $2 \mu \mathrm{g} \mathrm{ml}^{-1}$ final concentration) in the dark for $5 \mathrm{~min}$, and filtered onto $0.2 \mu \mathrm{m}$ black polycarbonate filters (GTBP, Millipore). At least 300 cells per filter were counted under a Leitz Axioplan 2 at 1000× magnification. The abundance of the 'particle-attached bacteria' was calculated as the difference of the abundance of the whole community and the free-living cells. The abundance of large free-living bacteria was calculated as the difference between the abundance of total free-living cells and the small free-living cells.

${ }^{3} \mathrm{H}$-leucine incorporation by bacteria, subsequently referred to as bacterial heterotrophic production (BHP), was measured on the whole (unfiltered), $3 \mu \mathrm{m}$ filtered and $0.8 \mu \mathrm{m}$ filtered bacterial community. The
BHP of the attached community and of the large freeliving community was calculated as described above for bacterial abundance. Two $5 \mathrm{ml}$ samples and 1 formaldehyde-killed blank were inoculated with ${ }^{3} \mathrm{H}$ leucine $(20 \mathrm{nM}$ final concentration; specific activity $160 \mathrm{Ci} \mathrm{mmol}^{-1}$; Amersham) and incubated in the dark at in situ temperature for $4 \mathrm{~h}$. Subsequently, the samples were fixed with formaldehyde $(2 \%$ final concentration), filtered onto $0.45 \mu \mathrm{m}$ Millipore HA filters, and rinsed 3 times with $10 \mathrm{ml}$ of $5 \%$ ice-cold TCA. Thereafter, the filters were transferred into scintillation vials and dried at room temperature. Then, $1 \mathrm{ml}$ of ethyl acetate and $8 \mathrm{ml}$ of scintillation cocktail (Packard Gold Insta Gel) were added to each vial and counted in a LKB liquid scintillation counter after $18 \mathrm{~h}$. DPMs were used to calculate the molar incorporation rates of leucine that were subsequently converted to bacterial carbon production using the empirical conversion factor $0.07 \times 10^{18} \mathrm{cells} \mathrm{mol}^{-1}$ Leu (Riemann et al. 1990) and assuming a bacterial C-content of $20 \mathrm{fg} \mathrm{C} \mathrm{cell}^{-1}$ (Lee \& Fuhrman 1987). The application of this conversion factor resulted in similar bacterial production estimates as the theoretical factor of $1.55 \mathrm{~kg} \mathrm{C} \mathrm{mol}^{-1} \mathrm{Leu}$, assuming no isotope dilution (Simon \& Azam 1989) (data not shown).

Bacterial growth rates $\left(\mathrm{d}^{-1}\right)$ were calculated for the different fractions of the bacterial community as the BHP of a specific fraction divided by the corresponding bacterial biomass, calculated from the bacterial abundance assuming a carbon content of $20 \mathrm{fg} \mathrm{C} \mathrm{Cell}^{-1}$ (Lee \& Fuhrman 1987).

Microbial respiration (R) was determined via the change in $\mathrm{O}_{2}$ during $24 \mathrm{~h}$ incubations in gas tight biological oxygen demand (BOD) bottles. Briefly, water was gently filtered through 3 and $0.8 \mu \mathrm{m}$ rinsed polycarbonate filters, and each fraction was distributed in 6 calibrated borosilicate BOD bottles $(120 \mathrm{ml}$ nominal volume) avoiding the inclusion of air bubbles and incubated for $24 \mathrm{~h}$. High precision spectrophotometric Winkler titrations (Reinthaler et al. 2005) were used to determine $\mathrm{O}_{2}$ concentrations. To determine the initial oxygen concentration $\left(\mathrm{T}_{0}\right)$, triplicate samples were fixed immediately with Winkler reagents and incubated together with the triplicate live samples in a water bath in the dark at in situ temperature. After $24 \mathrm{~h}$, the incubation was terminated by adding the Winkler reagents to the live samples $\left(\mathrm{T}_{1}\right)$.

The measured oxygen consumption (for the 3 and the $0.8 \mu \mathrm{m}$ prefiltered water) was transformed to carbon units assuming a respiratory quotient of 1 . Bacterial carbon demand (BCD) was calculated as BHP + R. Bacterial growth efficiency (BGE) was calculated as BHP/BCD for the different fractions.

Flagellate abundance. Twenty $\mathrm{ml}$ samples of $3 \mu \mathrm{m}$ filtered and unfiltered water were fixed with glu- 
taraldehyde ( $2 \%$ final concentration) and kept at $4{ }^{\circ} \mathrm{C}$ for at least $30 \mathrm{~min}$. The fixed samples were then stained with DAPI ( $2 \mu \mathrm{g} \mathrm{ml}^{-1}$ final concentration) for 5 to $10 \mathrm{~min}$, filtered onto $0.6 \mu \mathrm{m}$ black polycarbonate filters and counted by epifluorescence microscopy (Zeiss Axioplan 2, 1000× magnification).

Viral abundance and production. Viral abundance was measured by epifluorescence microscopy after SYBR Green I staining (Noble \& Fuhrman 1998, Patel et al. 2007). Briefly, $1 \mathrm{ml}$ samples of unfiltered water were fixed ( $2 \%$ final concentration of $0.02 \mu \mathrm{m}$ filtered formaldehyde) and stored at $4^{\circ} \mathrm{C}$ for 10 to $30 \mathrm{~min}$. Thereafter, the samples were filtered onto $0.02 \mu \mathrm{m}$ Anodisc filters (Whatman), stained for $15 \mathrm{~min}$ in the dark with SYBR Green I (Molecular Probes) at a final concentration of 2.5/1000 from the manufacturer's stock solution. After carefully removing excess stain with Kimwipe paper (Kimberly-Clark), the filters were mounted on slides with $0.1 \%(\mathrm{v} / \mathrm{v}) p$-phenylenediamine anti-fade mounting medium and examined under blue excitation with a Zeiss Axioplan microscope at $1250 \times$ magnification. At least 200 virus-like particles were counted per filter.

Viral production was measured by the dilution approach (Wilhelm et al. 2002). Briefly, $2 \mathrm{ml}$ of the bacterial concentrate obtained by $0.2 \mu \mathrm{m}$ tangential flow ultrafiltration (Vivascience) was added to $50 \mathrm{ml}$ of virus-free filtrate produced from the same water sample using a $30 \mathrm{kDa}$ membrane (Vivascience). Initial bacterial abundance in dilution experiments were similar to in situ abundance. Subsamples were taken to enumerate bacteria and viruses at $4 \mathrm{~h}$ intervals over a time span of $24 \mathrm{~h}$. The experiments were performed in duplicate at in situ temperature in the dark. Under these conditions, it is assumed that the increase in viral abundance during the incubation period resulted from the lytic phase of previously infected bacterioplankton from the natural environment (Wilhelm et al. 2002).

\section{RESULTS}

\section{Phytoplankton biomass and production}

The phytoplankton biomass, expressed as chl a concentration, showed 2 maxima during this annual cycle, one between the end of March and mid April, and a second one between mid May and early June (Fig. 1A). The first phytoplankton maxima was initiated by a diverse diatom bloom (G. C. Cadée, C. J. M. Philippart \& J. M. Van Ipperen unpubl.), which reached a concentration of $2.1 \times 10^{3}$ cells $\mathrm{ml}^{-1}$ and was followed by a bloom of Phaeocystis globosa (Fig. 1B). During its peak, P. globosa comprised $97 \%$ of total algal cell counts and reached a maximum of $60 \times 10^{3}$ cells ml $^{-1}$ (colonial + flagellate cells). The second phytoplankton biomass peak was characterized by a more diverse community than the first phytoplankton peak, however, with high contributions of Phaeocystis (on average $23 \%$ and up to $51 \%$ of the total counts) and diatoms (on average $16 \%$ and up to $43 \%$ of the cell counts).

The PPP measured under in situ radiation conditions and under constant light were very similar (Fig. 1C), with a major peak in April during the first Phaeocystis bloom. From December until mid March, PPP was very low (mean value $1.39 \mathrm{mmol} \mathrm{C} \mathrm{m}^{-2} \mathrm{~d}^{-1}$ ). Photosynthetic extracellular release rates (PER) maxima coincided with the phytoplankton blooms and were greatest in April and at the end of May (Fig. 1D). The percentage of PER followed roughly the pattern of PER during the spring phytoplankton bloom; however, it was overall more variable with up to $12 \%$ PER when the rate of PER was low during the summer and early fall (Fig. 1D).

\section{Dissolved organic matter dynamics}

DOC, DON and DOP concentrations along with their ratios are shown in Fig. 2 and in Table S1 in the supplement available at www.int-res.com/articles/suppl/ a060p085_app.pdf. DOC showed a variable pattern, with a general tendency to increase from the winter towards the summer. DOC concentrations varied only by a factor of 2.4 over the annual cycle. DON and DOP displayed a more pronounced seasonal pattern than DOC, with increasing concentrations from winter until July-August and decreasing thereafter again towards the winter.

Despite some week-to-week variability of the DOM concentrations, several periods can be distinguished over the annual cycle in the coastal North Sea: a period of DOM accumulation from the end of January to early June (coinciding with the end of the phytoplankton blooms) when DOC ( $\mathrm{r}=0.60, \mathrm{p}=0.003)$, DON ( $\mathrm{r}=0.81$, $\left.\mathrm{p}=6 \times 10^{-6}\right)$, DOP $\left(\mathrm{r}=0.91, \mathrm{p}=4 \times 10^{-9}\right)$ and dissolved proteins $(\mathrm{r}=0.74, \mathrm{p}=0.0001)$ significantly increased with time over this $127 \mathrm{~d}$ period. This was followed by a DOM removal period from the end of August to mid December (Fig. 2, Table S1). During this period, the total DOC decrease was $101 \mu \mathrm{mol} \mathrm{Cl^{-1 }}(\mathrm{r}=-0.41, \mathrm{p}=$ $0.1)$, DON decreased by $9.7 \mu \mathrm{mol} \mathrm{l}^{-1}(\mathrm{r}=-0.71, \mathrm{p}=$ $0.006)$ and DOP by $0.28 \mu \mathrm{mol} \mathrm{l}^{-1}(\mathrm{r}=-0.93, \mathrm{p}=4.6 \times$ $\left.10^{-6}\right)$, i.e. 39,44 and $65 \%$ of the concentration at the end of August, respectively. This decrease in DOM coincided with a change in the DOC:DON:DOP ratio from 615:52:1 to 1061:83:1 (Table S1).

The DOC:DON ratio, averaged over the annual cycle, was $13.7 \pm 5.3$, and less variable than the DON:DOP and DOC:DOP ratios (116 \pm 203 and 1632 

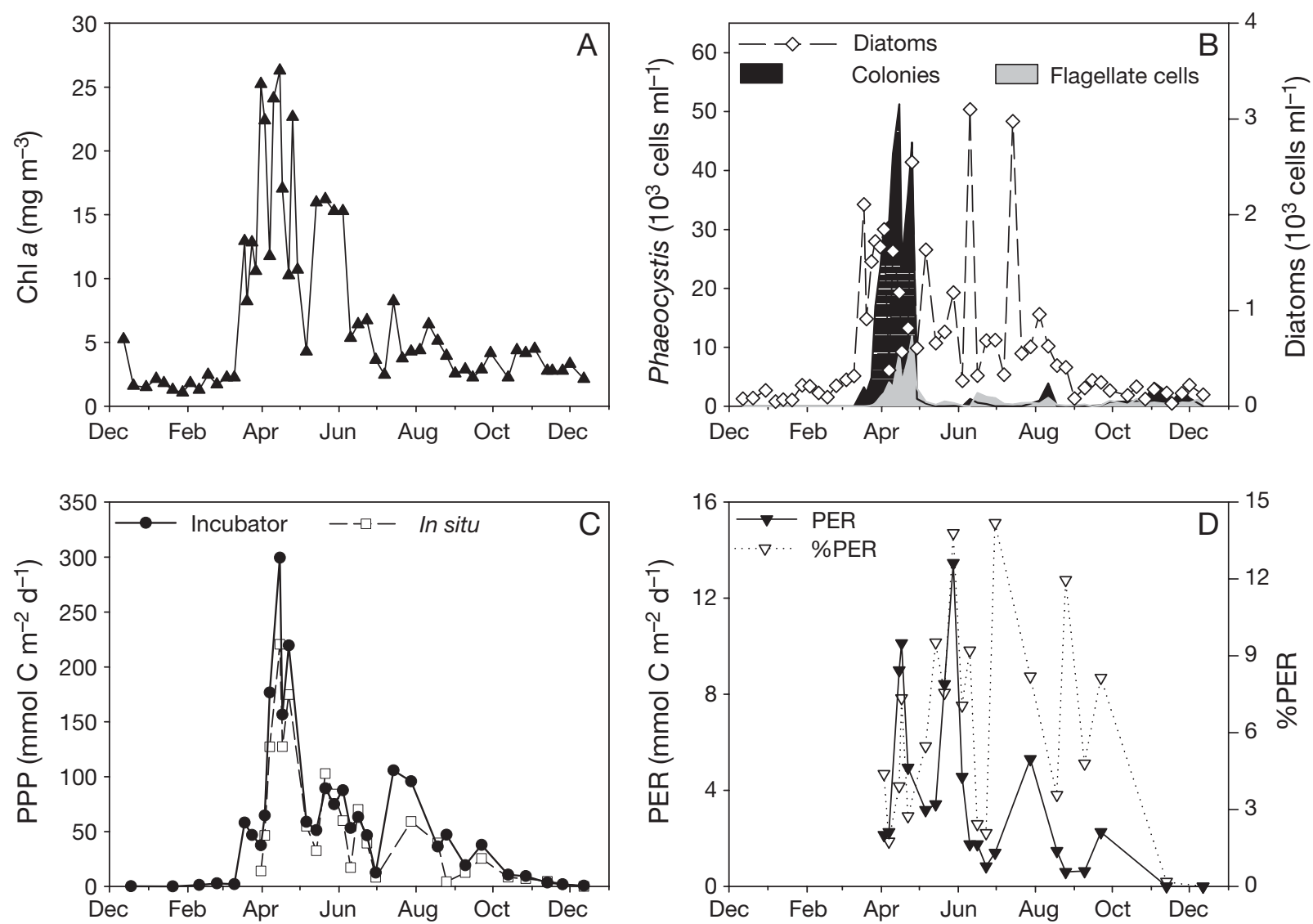

Fig. 1. Phytoplankton variability of (A) phytoplankton biomass as chlorophyll a concentrations ( $\mathbf{\Delta})$; (B) abundance of Phaeocystis cells: colonies (black area) or flagellate cells (grey area) and of marine diatoms $(\diamond)$; (C) particulate phytoplankton production (PPP) measured on the incubator at constant radiation conditions $(\bullet)$ and under in situ conditions ( $\square$ ); (D) photosynthetic extracellular release $(\mathrm{PER}, \mathbf{\nabla})$ and \% PER $(\nabla)$ under in situ conditions

\pm 2792 , respectively) (Table S1). The contribution of DON and DOP to the TDN and TDP, respectively, was low during the winter (Table S1). The DOP contribution to TDP increased in spring following closely the Phaeocystis bloom and reaching a maximum of $86 \% 2 \mathrm{~d}$ after Phaeocystis attained highest biomass.

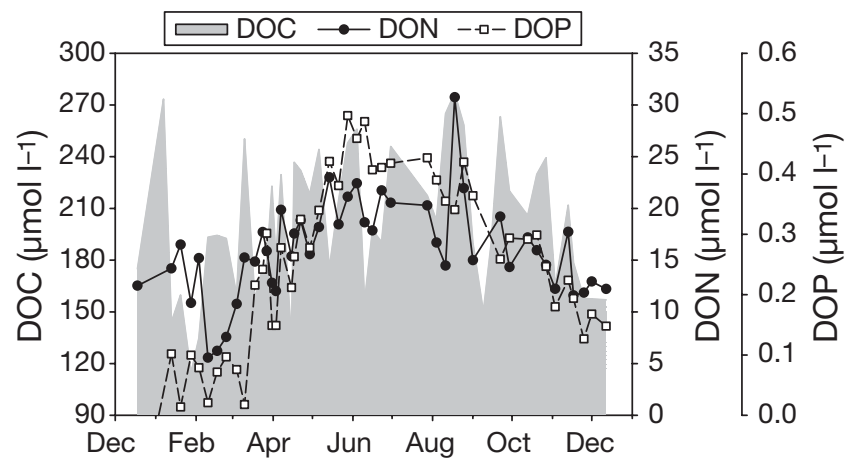

Fig. 2. Dissolved organic matter concentration in the coastal North Sea over the annual cycle: dissolved organic carbon (DOC, grey area), dissolved organic nitrogen (DON, $\bullet$ ) and dissolved organic phosphorus (DOP, $\square$ )
The DON contribution to TDN also gradually increased during the bloom with a delay of around $10 \mathrm{~d}$ as compared to the phytoplankton biomass and reached its maximum (92\%) $7 \mathrm{~d}$ after the peak of Phaeocystis. Both DON and DOP maintained a high contribution to TDN and TDP, respectively, throughout spring and summer (DOP > 53\% until end of July, DON > 64\% until end of September), decreasing again towards the fall and winter. DON and DOP concentrations varied by a factor of 5.5 and 35.5 over the seasons, respectively.

The ratio TDN:TDP was generally higher than the Redfield ratio, peaked during the Phaeocystis bloom and decreased towards the summer, when DOP constituted the major fraction of TDP (Table S1).

Dissolved protein concentration increased from a winter low (Fig. 3A) to a maximum that corresponded to phytoplankton blooms (Fig. 3A). Protein and DON concentrations showed a weak but significant positive relationship over the annual cycle $(\mathrm{r}=0.55, \mathrm{p}=$ 0.0002). The contribution of protein-N to DON, assuming a $16 \%$ nitrogen content of proteins, was 


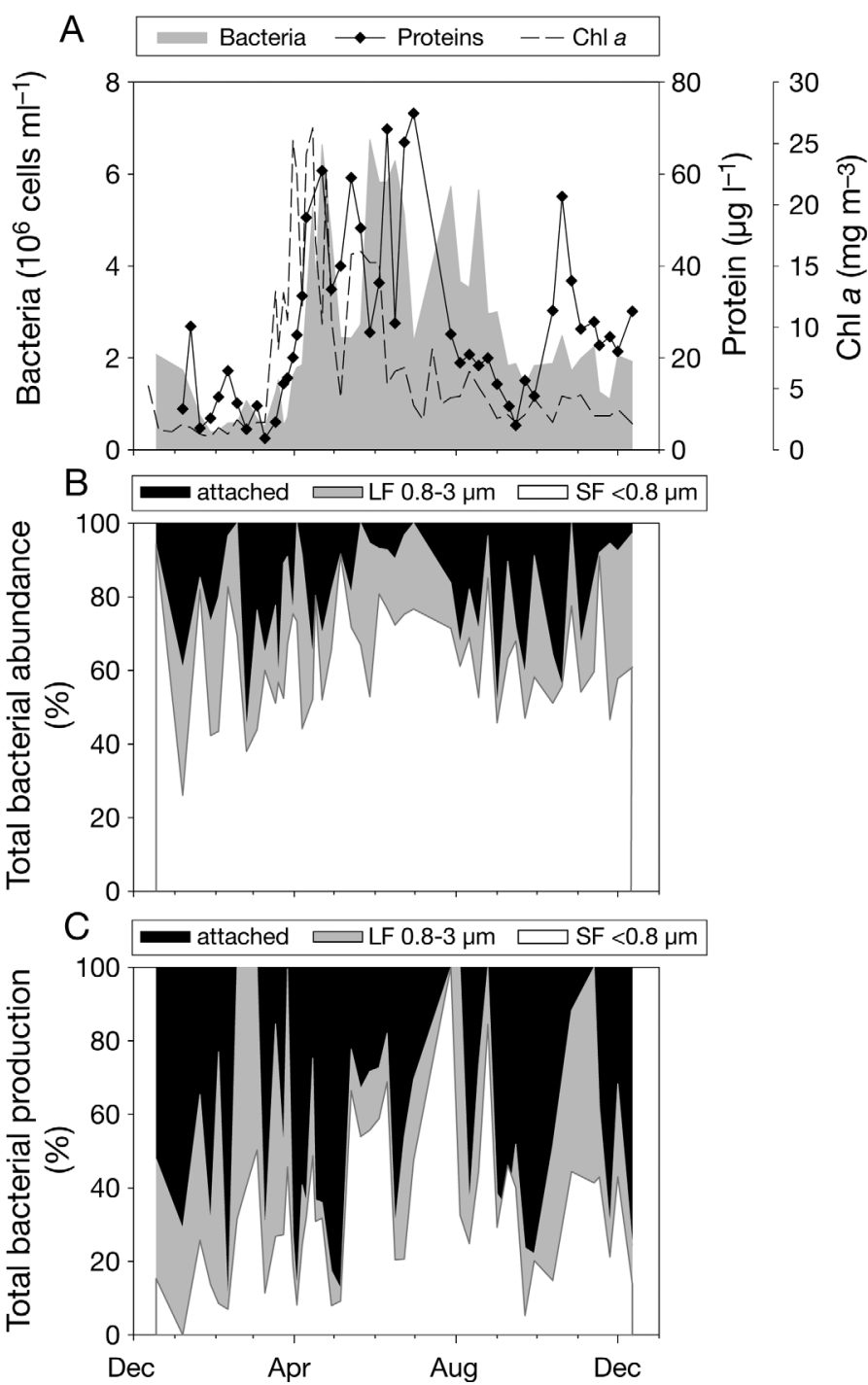

Fig. 3. (A) Dissolved protein concentration over the annual cycle. Chlorophyll $a$ and total abundance of bacteria are plotted as a reference. Contribution of attached (black area), large free-living (LF, light grey) and small free-living (SF, white) bacteria to total (B) bacterial abundance and (C) heterotrophic bacterial production

higher than the contribution of protein-C to DOC, assuming a $50 \% \mathrm{C}$ content, with an annual average contribution of $1.9 \%$ (ranging from 0.2 to $4.3 \%$ ) versus $0.5 \%$ (ranging from 0.04 to $1.9 \%$ ) to DON and DOC, respectively. The contribution of protein-N and protein-C to DON and DOC followed closely the annual variation in protein concentrations (Table S1, Fig. 3A). The protein concentration was also positively related to bacterial abundance, mainly with freeliving and small free-living cells $(r=0.55,0.62$ and $0.65, \mathrm{p}<0.0002$ for whole, free-living and small freeliving bacterial communities, respectively), however, only weakly to $\mathrm{chl}$ a $(\mathrm{r}=0.30, \mathrm{p}=0.04)$.

\section{Bacterial abundance and activity}

The variability of total bacterial abundance demonstrated similar trends to that of chl a but with a temporal delay of 2 to $7 \mathrm{~d}$ through mid July and became more variable thereafter (Fig. 3A). The contribution of the small $(<0.8 \mu \mathrm{m})$ and the large free-living cells $(0.8$ to $3 \mu \mathrm{m})$ co-varied over the seasonal cycle $\left(\mathrm{r}^{2}=0.32\right.$, $\mathrm{p}=0.00002$, Fig. 3B). Most of the free-living bacteria were in the $<0.8 \mu \mathrm{m}$ size class $(63 \pm 15 \%$ of the total bacteria) while only $19 \pm 14 \%$ were $>0.8 \mu \mathrm{m}$ in size. The percentage of attached bacteria was, on average, $18 \pm 15 \%$ of the total bacterial abundance, with higher contributions in the winter to early spring and in the fall. Fractionated BHP (Fig. 3C) did not follow the fractionated bacterial abundance (Fig. 3B). The attached BHP represented, on average, $44 \pm 29 \%$ of total BHP as compared to $18 \%$ of total bacterial abundance. The contribution of the large free-living cells $(0.8$ to $3 \mu \mathrm{m})$ to total BHP was, on average, $23 \pm 21 \%$, roughly similar to their contribution to total bacterial abundance of $19 \%$.

Picoplankton respiration peaked at the end of the 2 phytoplankton blooms and at the end of the summer (see Fig. S1 in the supplement available at www.intres.com/articles/suppl/a060p085_app.pdf). The small cells $(<0.8 \mu \mathrm{m})$ were responsible for up to $100 \%$ of the respiration of the free-living bacterial community (on average $63 \pm 29 \%$ ) .

Cell-specific heterotrophic production of the whole bacterial community was, on average, $1.06 \pm 1.20 \mathrm{fmol}$ C cell ${ }^{-1} \mathrm{~d}^{-1}$, of the large free-living bacterial cells 2.39 $\pm 5.49 \mathrm{fmol} \mathrm{C}$ cell $^{-1} \mathrm{~d}^{-1}$, of the attached cells $4.34 \pm$ $7.86 \mathrm{fmol} \mathrm{C} \mathrm{cell}^{-1} \mathrm{~d}^{-1}$, and of the small free-living cells $0.42 \pm 0.32 \mathrm{fmol} \mathrm{C}$ cell $^{-1} \mathrm{~d}^{-1}$ (see Table S2 in the supplement available at www.int-res.com/articles/suppl/ a060p085_app.pdf). Average specific growth rates for the total, attached, large and small free-living bacterial cells were $0.63 \pm 0.72,3.50 \pm 5.19,1.57 \pm 3.42$, and 0.26 $\pm 0.19 \mathrm{~d}^{-1}$, respectively. Both small and large freeliving bacteria showed higher cell-specific production during the initial phases of the phytoplanktonic blooms, while attached bacteria tended to have higher cell-specific production at the end of the blooms (Table S2). Cell-specific respiration showed similar annual patterns as cell-specific heterotrophic production, although additional peaks in cell-specific respiration were detectable at the collapse of the phytoplankton blooms and during the summer (Table S2).

Bacterial growth efficiencies (BGE) of the 2 freeliving bacterial communities (small- and large-sized cells), as well as the total free-living bacteria showed no clear seasonal dynamics (Table S2). Total freeliving and small free-living bacteria exhibited a very similar pattern resulting in an average BGE of $27 \pm$ 
$12 \%$ and $27 \pm 16 \%$, respectively. BGE of the large free-living cells was more variable, although not significantly higher $(35 \pm 24 \%)$ than the BGE of small free-living bacteria (Table S2).

The BCD of the free-living community was sustained by the PER rates during the main phytoplankton blooms (Fig. 4A) while additional DOM production sources supported $52 \%$ of BCD from August to December. PPP (on average $94 \%$ of the total primary produc-

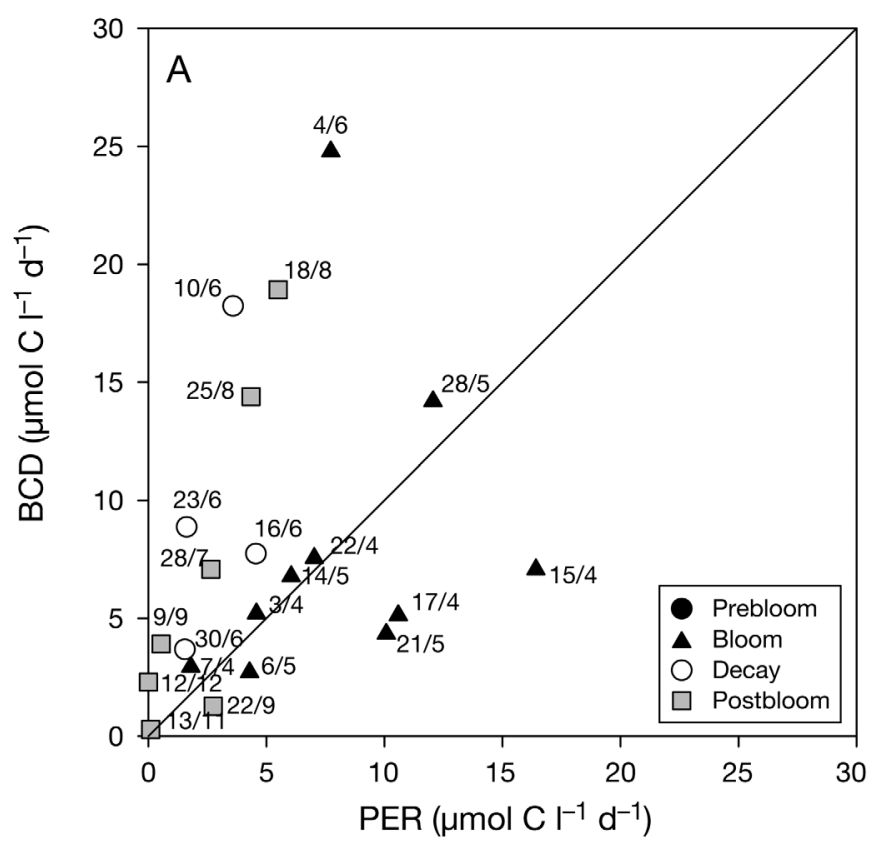

tion) was sufficient to support BCD during most of the year with the only exceptions during the period from mid December to mid January (Fig. 4B,C).

\section{Flagellate and viral abundance and viral production}

Flagellate abundance varied between 0.45 and 10.63 $\times 10^{3}$ cell ml-1, with maxima in spring and fall. Virus-

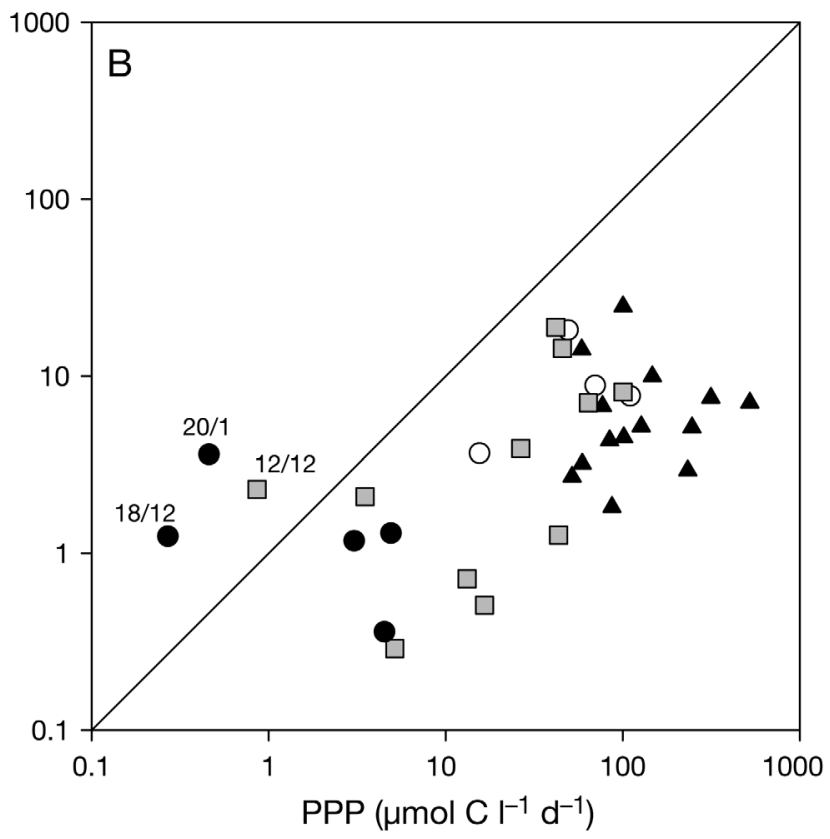

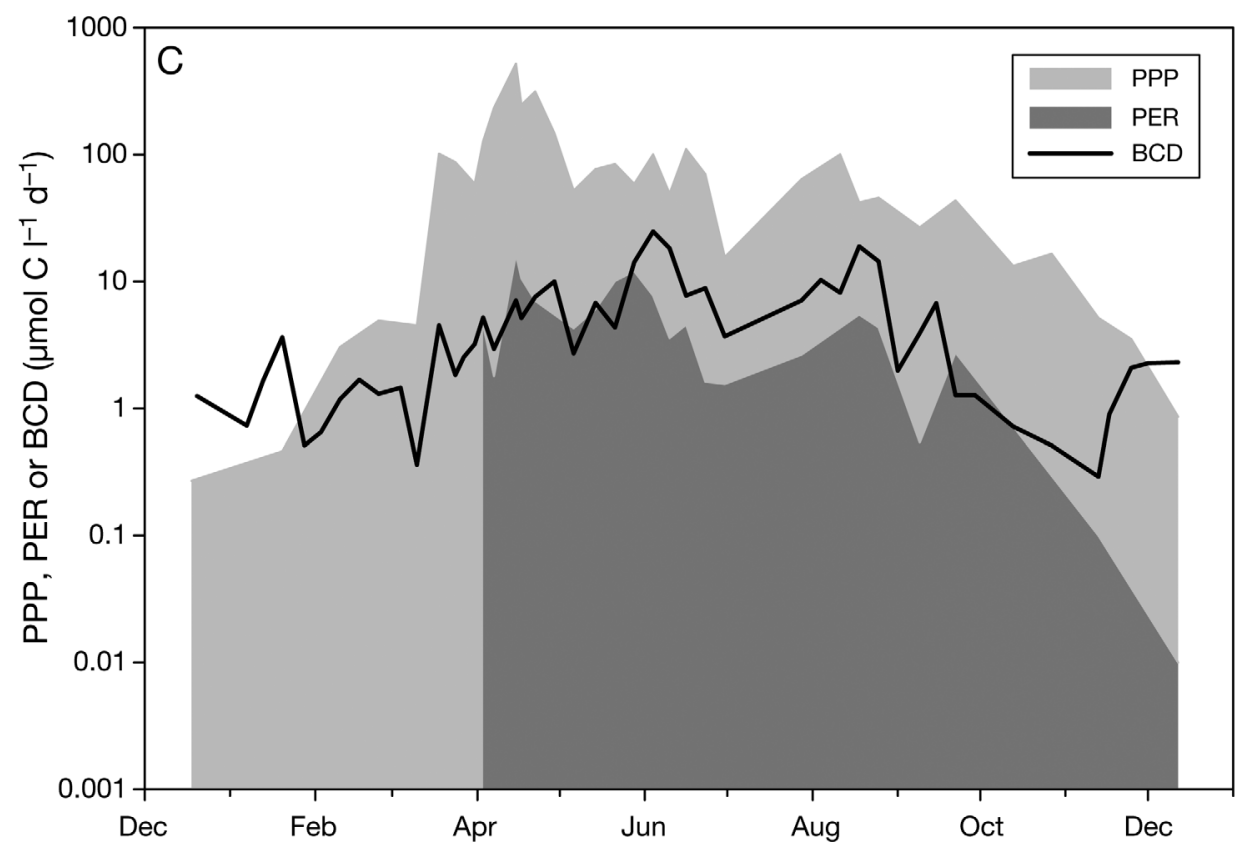

Fig. 4. Bacterial carbon demand (BCD) of the $3 \mu \mathrm{m}$-filtered fraction vs. (A) photosynthetic extracellular release (PER), (B) particulate phytoplankton production (PPP). Different symbols denote different stage of the phytoplankton bloom. (C) Seasonal dynamics of PPP, PER and BCD. PER was only measured from early April onward 
like particle (VLP) abundance ranged between 1.2 and $31.6 \times 10^{7} \mathrm{VLP} \mathrm{ml}^{-1}$ between March and December (see Fig. S2A in the supplement available at www.intres.com/articles/suppl/a060p085_app.pdf). Flagellate and VLP abundance exhibited a similar pattern as bacterial abundance during the spring and summer (Fig. S2A), with a delay of around 7 to $10 \mathrm{~d}$. During the fall and winter, the abundance of both groups was more variable and not related to bacterial and phytoplankton abundance. Viral production ranged between 0.57 and $178 \times 10^{7} \mathrm{VLP} \mathrm{ml}^{-1} \mathrm{~d}^{-1}$ and showed the same trends as viral abundance, with high variability during the fall-winter period and a delay of about $7 \mathrm{~d}$ in peak production compared to the bacterial production peaks (Fig. S2B). Highest viral production rates were determined in spring and the end of the fall (Fig. S2B).

\section{DISCUSSION}

\section{Organic matter accumulation and removal in the coastal North Sea}

A 1-dimensional treatment of the data shows a seasonal pattern of DOC production and subsequent removal. However, the negative correlation of DOC concentrations with salinity (Table S3 in the supplement available at www.int-res.com/articles/suppl/ a060p085_ app.pdf) indicates that freshwater inputs must also be considered during the winter periods. DON and DOP concentrations were not related with salinity indicating the input of $\mathrm{C}$ rich DOM during this time period (DOC:DON:DOP ratio of 3960:274:1 calculated as the average of the ratios for the winter period between December and beginning of March). This agrees with the typically higher $\mathrm{C}: \mathrm{N}$ ratios of organic matter from terrestrial origin (Meyers 1994, Gordon \& Goni 2003) and of humics (Thurman 1985). DOM and particularly dissolved proteins were dominantly of phytoplankton origin in spring, mainly during the Phaeocystis bloom. The significant correlations between dissolved protein and the abundance of phytoplankton ( $\mathrm{r}=0.90, \mathrm{p}<0.003)$ and Phaeocystis $(\mathrm{r}=0.91$, $\mathrm{p}<0.002$ ), and with the particulate primary production $(\mathrm{r}=0.89, \mathrm{p}<0.02)$ suggest that the magnitude of dissolved protein and its variability is constrained by primary production, although the exact mechanism of production is unknown (i.e. direct release vs. sloppy feeding, etc.).

Some variability in DOM concentration was observed for specific dates (Fig. 2, Table S1), which might be associated to episodic freshwater inflow indicated by a decrease in salinity (e.g. during the bloom period; Fig. S3 in the supplement available at www.int-res.com/articles/suppl/a060p085_app.pdf).
Despite this variability, clear seasonal trends in DOM are apparent. DOM concentrations increased from winter towards the summer (Fig. 2, Table S1) as reported earlier (van der Zee \& Chou 2005), indicating autochthonous production of DOM and its accumulation. This accumulation of DOM indicates the production of DOM that is resistant to rapid microbial degradation, nutrient limitation of BHP, or the introduction of allochthonous sources into the system such as via freshwater input, re-suspension of sediments related to wind and/or tidal effects and the subsequent release of DOM from the particles, and subtidal pumping of porewater into the overlying water column (Abril et al. 1999, Miller 1999). Overall, over most of the annual cycle, DOM was not related to phytoplankton parameters (Table S3).

PER rates were measured from 3 April onwards. Integrating PER and BCD over different time spans using the trapezoidal method allowed us to assess the potential contribution of PER to DOC accumulation (calculated as the difference between DOC concentrations over the different time spans) and BCD. The PER integrated between 3 April to 4 June amounted

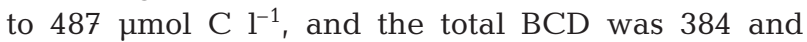

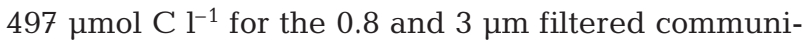
ties, respectively. Thus, $98 \%$ of the BCD could be accounted for by PER, suggesting tight coupling between DOM release via PPP and contemporaneous utilization of labile DOM by bacterioplankton. Despite this tight

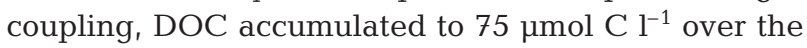
same time period indicating that additional DOM production mechanisms (i.e. zooplankton sloppy feeding, POM solubilization, viral lysis; see Carlson 2002) resulted in the production of DOM that escaped rapid microbial utilization. Alternatively, some high molecular weight PER might have been retained on the GF/F filters (Janse et al. 1996) and, therefore, were not measured with our approach.

The contribution of PER to BCD changed dramatically from spring-summer to autumn-winter indicating a shift in the sources of DOM used to support BCD. Compared to the spring, only $48 \%$ of BCD could be explained by PER from August to December. During this time $\sim 101 \mu \mathrm{M}$ of the bulk DOC pool was removed suggesting the utilization of more recalcitrant DOM may have been used to support BCD. However, the vertical or horizontal export of DOM from the study site cannot be ruled out and could have contributed to this removal. It must be noted that the PPP was, except for a short period in winter, always sufficient to meet the BCD (Fig. 4) indicating net autotrophy.

The PPP as well as the BCD in the coastal North Sea are substantially higher than the corresponding values reported for the open North Sea (Reinthaler \& Herndl 2005). For the open North Sea, Reinthaler \& Herndl 
(2005) concluded that the BCD (corresponding to our small free-living bacteria) amounts to $70 \%$ of the PPP indicating that autochthonously produced organic matter is sufficient to support BCD also in the open North Sea (Reinthaler \& Herndl 2005). During this study, we found that in the coastal North Sea, the BCD of small free-living bacteria is only $4 \%$ of the PPP over the annual cycle (and $5 \%$ for the $<3 \mu \mathrm{m}$ size fraction). Thus, the autochthonous phytoplankton production is not only sufficient to support BCD, but a large fraction of the phytoplankton production is potentially available for higher trophic levels (such as zooplankton) and/or for export (e.g. to the benthic system by sedimentation).

\section{Bottom-up vs. top-down control of bacterial commu- nities of the coastal North Sea}

The control of the bacterial community can be inferred from correlations between the resources (i.e. DOM concentration) and the consumers (i.e. bacteria), or between the biomass or the production of the substrate producers (i.e. phytoplankton) and the biomass or production of substrate consumers (i.e. bacteria). Positive correlations would suggest a control of the bacterial biomass by resources derived from phytoplankton.

In the coastal North Sea, bacterial production is positively correlated with dissolved protein concentration over the annual cycle (except for the attached and the large free-living cells), with DOP (except the attached bacteria) and DON (only the free-living cells), but not with DOC (Table S4 in the supplement available at www.int-res.com/articles/suppl/a060p085_app.pdf). This might indicate that a major fraction of the DOC is rather refractory for the bacterial community, while DON, dissolved protein concentrations and DOP seem to be highly reactive. Taken together, our results indicate an increasing reactivity from DOC $<$ DON $<$ DOP as reported for several marine systems (Ogawa et al. 1999, Abell et al. 2000, Ogawa \& Tanoue 2003). Additionally, the production of both small and large freeliving cells was slightly (Table S4) negatively related to DOC:DON ratios, indicating that DOM of lower C:N ratios is of higher nutritional quality for heterotrophic bacteria (Hopkinson et al. 1998, Wiegner \& Seitzinger 2004).

Also, positive relationships were found with chlorophyll and abundance of marine diatoms and other phytoplankton, while the abundance of Phaeocystis only correlated with the attached bacterial production (Table S4). The latter might be related to the release of mucopolysaccharides by this phytoplankton species and the subsequent colonization by bacteria. PPP and
PER were not significantly related to bacterial heterotrophic production, but with bacterial abundance in all fractions. This lack of correlation seems not to be related to a time lag between the phytoplanktonic production and the consumption by bacteria, as applying a time delay does not result in a better correlation, but might be due to the consumption of allochthonous DOM or to the presence of more refractory DOM (Thingstad et al. 1997).

No significant relationships were found between bacterial abundance or production with the abundance of flagellates (except for the attached bacteria), viral abundance, or production (Table S4) indicating an inefficient top-down control of the free-living bacteria by predators. This conclusion differs from the findings of Winter et al. (2005) who found a significant correlation between viral abundance and bacterial production over a seasonal cycle in the open North Sea. This contrasting pattern between open and coastal North Sea indicates that viruses in the coastal North Sea are less efficient in controlling bacterioplankton than in the open North Sea, which might be explained by a higher load of particles in coastal waters scavenging viruses from the water column (Hewson \& Fuhrman 2003).

Other environmental factors can influence the DOM uptake by the bacteria as well, such as temperature. A significant relationship was found between bacterial production and temperature, but only for the freeliving bacteria (Table S4) supporting the idea that the attached community is less affected by environmental and biotic conditions in the surrounding water, such as temperature and ambient inorganic and organic nutrient concentrations.

Summarizing, DOC might originate partially from freshwater input, mainly in winter, and from phytoplankton thereafter, but the apparent inability of the heterotrophic microbial community to efficiently degrade the introduced DOM leads to an accumulation of the DOC during spring and summer. Overall, these results indicate a pronounced shift towards utilization of more refractory or older DOM during the second half of the annual cycle.

Acknowledgements. We thank the NIOZ personnel involved in the MARSDIEP monitoring series for providing the physical data, inorganic nutrient concentrations, chl $a$, phytoplankton community composition, and part of the particulate primary production. Wind direction and wind speed data was obtained from The Royal Netherlands Meteorological Institute (www.knmi.nl/klimatologie/daggegevens/index.cgi). The thorough revision of an earlier version of the manuscript by $\mathrm{C}$. A. Carlson is gratefully acknowledged. Financial support was provided by the BASICS project (EVK3-CT-2002-00078) from the European Union to G.J.H. and K.S., a Marie Curie Intraeuropean fellowship (MEIF-CT-2003-500808) to E.S. and an ALW-NWO (Earth and Life Science branch of the Dutch Science Foundation) project to G.J.H. 


\section{LITERATURE CITED}

Abell J, Emerson S, Renaud P (2000) Distributions of TOP, TON and TOC in the North Pacific subtropical gyre: implications for nutrient supply in the surface ocean and remineralization in the upper thermocline. J Mar Res 58: 203-222

Abril G, Etcheber $\mathrm{H}$, Le Hir P, Bassoullet $\mathrm{P}$, Boutier B, Frankignoulle $M$ (1999) Oxic/anoxic oscillations and organic carbon mineralization in an estuarine maximum turbidity zone (The Gironde, France). Limnol Oceanogr 44:1304-1315

Artolozaga I, Valcarcel M, Ayo B, Latatu A, Iriberri J (2002) Grazing rates of bacterivorous protists inhabiting diverse marine planktonic microenvironments. Limnol Oceanogr 47:142-150

Azam F, Fenchel T, Field JG, Gray JS, Meyer-Reil LA, Thingstad F (1983) The ecological role of water-column microbes in the sea. Mar Ecol Prog Ser 10:257-263

Benner R, Strom M (1993) A critical evaluation of the analytical blank associated with DOC measurements by hightemperature catalytic-oxidation. Mar Chem 41:153-160

Buijsman MC, Ridderinkhof H (2007) Water transport at subtidal frequencies in the Marsdiep inlet. J Sea Res 58: 255-268

Buijsman MC, Ridderinkhof H (2008) Variability of secondary currents in a weakly stratified tidal inlet with low curvature. Cont Shelf Res 28:1711-1723

> Cadée GC, Hegeman J (2002) Phytoplankton in the Marsdiep at the end of the 20th century; 30 years monitoring biomass, primary production, and Phaeocystis blooms. J Sea Res 48:97-110

Carlson CA (2002) Production and removal processes. In: Hansell DA, Carlson CA (eds) Biogeochemistry of marine dissolved organic matter. Academic Press, San Diego, CA, p 91-152

Fuhrman JA (1999) Marine viruses and their biogeochemical and ecological effects. Nature 399:541-548

> Gordon ES, Goni MA (2003) Sources and distribution of terrigenous organic matter delivered by the Atchafalaya River to sediments in the northern Gulf of Mexico. Geochim Cosmochim Acta 67:2359-2375

Grossart HP, Kiorbøe T, Tang KW, Allgaier M, Yam EM, Ploug $\mathrm{H}$ (2006) Interactions between marine snow and heterotrophic bacteria: aggregate formation and microbial dynamics. Aquat Microb Ecol 42:19-26

> Grossart HP, Tang KW, Kiorbøe T, Ploug H (2007) Comparison of cell-specific activity between free-living and attached bacteria using isolates and natural assemblages. FEMS Microbiol Lett 266:194-200

Hewson I, Fuhrman JA (2003) Viriobenthos production and virioplankton sorptive scavenging by suspended sediment particles in coastal and pelagic waters. Microb Ecol 46: 337-347

Hopkinson CS, Buffam I, Hobbie J, Vallino J and others (1998) Terrestrial inputs of organic matter to coastal ecosystems: an intercomparison of chemical characteristics and bioavailability. Biogeochemistry 43:211-234

Janse I, van Rijssel M, Gottschal JC, Lancelot C, Gieskes WWC (1996) Carbohydrates in the North Sea during spring blooms of Phaeocystis: a specific fingerprint. Aquat Microb Ecol 10:97-103

Kiorbøe T, Grossart HP, Ploug H, Tang K, Auer B (2004) Particle-associated flagellates: swimming patterns, colonization rates, and grazing on attached bacteria. Aquat Microb Ecol 35:141-152

Kirchman DL, Moran XAG, Ducklow H (2009) Microbial growth in the polar oceans: role of temperature and potential impact of climate change. Nat Rev Microbiol 7:451-459

Kramer GD, Pausz C, Herndl GJ (2005) Elemental composition of dissolved organic matter and bacterioplankton production in the Faroe-Shetland Channel (North Atlantic). Deep-Sea Res I 52:85-97

> Lancelot C, Mathot S (1987) Dynamics of a Phaeocystis-dominated spring bloom in Belgian coastal waters. I. Phytoplanktonic activities and related parameters. Mar Ecol Prog Ser 37:239-248

> Lee S, Fuhrman JA (1987) Relationships between biovolume and biomass of naturally derived marine bacterioplankton. Appl Environ Microbiol 53:1298-1303

Lee CW, Kudo I, Yanada M, Maita Y (2001) Bacterial abundance and production and heterotrophic nanoflagellate abundance in subarctic coastal waters (Western North Pacific Ocean). Aquat Microb Ecol 23:263-271

Lorenzen CJ (1967) Determination of chlorophyll and phaeopigments: spectrophotometric equations. Limnol Oceanogr 12:343-346

Mari X, Rassoulzadegan F, Brussaard CPD, Wassmann P (2005) Dynamics of transparent exopolymeric particles (TEP) production by Phaeocystis globosa under N- or Plimitation: a controlling factor of the retention/export balance. Harmful Algae 4:895-914

Mari X, Kerros ME, Weinbauer MG (2007) Virus attachment to transparent exopolymeric particles along trophic gradients in the southwestern lagoon of New Caledonia. Appl Environ Microbiol 73:5245-5252

> Meyers PA (1994) Preservation of elemental and isotopic source identification of sedimentary organic-matter. Chem Geol 114:289-302

Miller AEJ (1999) Seasonal investigations of dissolved organic carbon dynamics in the Tamar Estuary, UK. Estuar Coast Shelf Sci 49:891-908

> Murray AG, Jackson GA (1992) Viral dynamics: a model of the effects of size, shape, motion and abundance of singlecelled planktonic organisms and other particles. Mar Ecol Prog Ser 89:103-116

Noble RT, Fuhrman JA (1998) Use of SYBR Green I for rapid epifluorescence counts of marine viruses and bacteria. Aquat Microb Ecol 14:113-118

Ogawa H, Tanoue E (2003) Dissolved organic matter in oceanic waters. J Oceanogr 59:129-147

> Ogawa H, Fukuda R, Koike I (1999) Vertical distributions of dissolved organic carbon and nitrogen in the Southern Ocean. Deep-Sea Res I 46:1809-1826

> Patel A, Noble RT, Steele JA, Schwalbach MS, Hewson I, Fuhrman JA (2007) Virus and prokaryote enumeration from planktonic aquatic environments by epifluorescence microscopy with SYBR Green I. Nat Protoc 2:269-276

Philippart CJM, Beukema JJ, Cadée GC, Dekker R and others (2007) Impacts of nutrient reduction on coastal communities. Ecosystems 10:95-118

Pomeroy LR, Wiebe WJ (2001) Temperature and substrates as interactive limiting factors for marine heterotrophic bacteria. Aquat Microb Ecol 23:187-204

Porter KG, Feig YS (1980) The use of DAPI for identifying and counting aquatic microflora. Limnol Oceanogr 25:943-948

Reinthaler T, Herndl GJ (2005) Seasonal dynamics of bacterial growth efficiencies in relation to phytoplankton in the southern North Sea. Aquat Microb Ecol 39:7-16

Reinthaler T, Winter C, Herndl GJ (2005) Relationship between bacterioplankton richness, respiration, and production in the southern North Sea. Appl Environ Microbiol 71:2260-2266

Riemann L, Grossart HP (2008) Elevated lytic phage produc- 
tion as a consequence of particle colonization by a marine Flavobacterium (Cellulophaga sp.). Microb Ecol 56: 505-512

Riemann B, Bell RT, Jorgensen NOG (1990) Incorporation of thymidine, adenine and leucine into natural bacterial assemblages. Mar Ecol Prog Ser 65:87-94

Simon M, Azam F (1989) Protein content and protein synthesis rates of planktonic marine bacteria. Mar Ecol Prog Ser 51:201-213

Smith PK, Krohn RI, Hermanson GT, Mallia AK, and 6 others (1985) Measurement of protein using bicinchoninic acid. Anal Biochem 150:76-85

Teira E, Pazo MJ, Serret P, Fernandez E (2001) Dissolved organic carbon production by microbial populations in the Atlantic Ocean. Limnol Oceanogr 46:1370-1377

Thingstad TF, Hagström A, Rassoulzadegan F (1997) Accumulation of degradable DOC in surface waters: Is it caused by a malfunctioning microbial loop? Limnol Oceanogr 42:398-404

Thurman EM (1985) Organic geochemistry of natural waters. M. Nijhoff \& W. Junk, Dordrecht

Valderrama JC (1981) The simultaneous analysis of total nitrogen and total phosphorus in natural waters. Mar

Editorial responsibility: Craig Carlson,

Santa Barbara, California, USA
Chem 10:109-122

Van der Zee C, Chou L (2005) Seasonal cycling of phosphorus in the Southern Bight of the North Sea. Biogeosciences 2:27-42

Van Wambeke F, Ghiglione JF, Nedoma J, Mevel G, Raimbault P (2009) Bottom up effects on bacterioplankton growth and composition during summer-autumn transition in the open NW Mediterranean Sea. Biogeosciences 6:705-720

Wiegner TN, Seitzinger SP (2004) Seasonal bioavailability of dissolved organic carbon and nitrogen from pristine and polluted freshwater wetlands. Limnol Oceanogr 49: 1703-1712

Wilhelm SW, Brigden SM, Suttle CA (2002) A dilution technique for the direct measurement of viral production: a comparison in stratified and tidally mixed coastal waters. Microb Ecol 43:168-173

Winter C, Smit A, Szoeke-Denes T, Herndl GJ, Weinbauer MG (2005) Modelling viral impact on bacterioplankton in the North Sea using artificial neural networks. Environ Microbiol 7:881-893

- Zimmerman JTF (1976) Mixing and flushing of tidal embayments in Western Dutch Wadden Sea. 2. Analysis of mixing processes. Neth J Sea Res 10:397-439

Submitted: December 2, 2008; Accepted: January 15, 2010 Proofs received from author(s): April 22, 2010 